\title{
The Interaction Between Area and Production of Food Grain Crops in India : An Empirical Evidence from ADRL Bounds Test Cointegration
}

RAJARATHINAM A ( $\sim$ arrathinam@yahoo.com )

Manonmaniam Sundaranar University https://orcid.org/0000-0002-3245-3181

Subha S S

Manonmaniam Sundaranar University

\section{Research Article}

Keywords: Autoregressive Distributed Lag Model, Error Correction Model, Unit Root Tests, Residual Diagnostics, Bounds Cointegration Test, Stability Tests

Posted Date: June 21st, 2021

DOl: https://doi.org/10.21203/rs.3.rs-640183/v1

License: (c) (i) This work is licensed under a Creative Commons Attribution 4.0 International License.

Read Full License 


\section{The Interaction Between Area and Production of Food Grain Crops in India : An} Empirical Evidence from ADRL Bounds Test Cointegration

$$
\text { Rajarathinam, } \mathrm{A}^{1} \text { and Subha, S.S. }{ }^{2}
$$

Department of Statistics, Manonmaniam Sundaranar University, Tirunelveli - 267012 Tamil Nadu State, India;

Emails: arrathinam@yahoo.com ${ }^{1}$ and sssubha@gmail.com²

Conflicts of Interest : The Authors have no conflict of Interest

\section{ABSTRACT}

This paper demonstrates a significant long-run relationship between area and productions of Food grain crops grown in India during the period 1950-2018. Stability of the estimated model parameters are studied. To assess the consistency of the model parameters the cumulative sum of recursive residuals test and the cumulative sum of recursive residuals squares tests are used.Additionally, cointegration equations such as the Fully Modified Ordinary Least Square Dynamic Ordinary Least Squares, and Canonical Cointegration Regression are applied to check the long-run elasticities in the concerned relationship.

\section{Short title:ADRL Model for Food grain production.}

Keywords: Autoregressive Distributed Lag Model, Error Correction Model, Unit Root Tests, Residual Diagnostics, Bounds Cointegration Test, Stability Tests

\section{INTRODUCTION}

\subsection{Background of the study}

Over the last few decades Regression modeling have traditionally being employed in predictions and classifications of agricultural production. For the agricultural planning purposes, decision makers need simple and reliable estimation techniques for the prediction of crop production. The multiple regression, discriminant analysis, factor analysis, principal component analysis, cluster analysis and logistic regression analysis etc., are the most used statistical techniques for prediction and classifications of agricultural related productions. Since in the agricultural production time series data, the problems of multicollinearity, autocorrelation and extreme values are unavoidable. In such a complex situations regression models may not provide accurate predictions.As regression models need to fulfil the regression assumptions such as autocorrelation and multiple co-linearity between

${ }^{1}$ Corresponding Author : arrathinam@yahoo.com 
independent variables, which causes the estimated regression models are unfits and the estimated parameter values obtained based on these models are found to be inefficient. (Zaefizadah et al. 2011). Most of the agricultural practices, crop production is influenced by a great variety of interrelated factors such as autocorrelation and it is difficult to describe their relationships by conventional methods. Hence in the present study the, Auto-regressive Distributed Lag Model (ADRL) is used to combat the complicated relations and strong autocorrelation presents in the crop production data.

\subsection{ADRL Methodological Literature Reviews}

Granger (1988) demonstrated that causal relations among variables could be examined within the framework of an error correction model (ECM) with cointegrated variables. While the short-run dynamics are captured by the individual coefficients on the lagged terms, the error correction term (ECT) contains information on long-run causality. The significance of the lagged explanatory variable identifies short-run causality, while a negative and statistically significant ECT signifies long-run causality.

Alimi, (2014) investigated the relationship between expected inflation and nominal interest rates in Nigeria and the extent to which the Fisher effect held for the period 1970-2021. He applied ARDL bounds testing and vector error correction (VECM), and the stability of the function was also tested by the CUSUM and CUSUMSQ tests. Finally, the CUSUM test confirmed the long-run relationship between the variables and showed the stability of the coefficients.

Nkoro and Uko, (2016), narrated and provided sufficient insight into the issues surrounding ARDL cointegration technique to young practitioners to enable them to properly apply, estimate, and interpret within the context of ARDL cointegration framework.This study shows that the adoption of the ARDL cointegration technique does not require pre-tests for unit roots unlike other techniques. Consequently, ARDL cointegration technique is preferable when dealing with variables that are integrated of different order, I(0), I(1) or combination of bothand, robust when there is a single long run relationship between the underlying variables in a small sample size. The long run relationship of the underlying variables is detected through the F-statistic (Wald test). In this approach, long run relationship of the series is said to be established when the Fstatistic exceeds the critical value band. The major advantage of this approach lies in its identification of the cointegrating vectors where there are multiple 
cointegrating vectors. However, this technique will crash in the presence of integrated stochastic trend of I(2). To forestall effort in futility, it may be advisable to test for unit roots, though not as a necessary condition. Based on forecast and policy stance, there is need to explore the necessary conditions that give rise to ARDL cointegration technique in order to avoid its wrongful application, estimation, and interpretation. If the conditions are not followed, it may lead to model misspecification and inconsistent and unrealistic estimates with its implication on forecast and policy.

Chandio et al., (2019), examined the effect of support price on wheat production in Pakistan during the period 1971-2016. The study confirmed the presence of a positive and long-term effect of area under cultivation, support price and fertilizer consumption on wheat production through ARDL bound test. The result showed that both in the long run and short run, support price plays an important role in the enhancement of wheat production. The authors also found that the coefficients of the area under cultivation and fertilizer consumption variables were statistically significant and positive both in the long run and short run.

Tursoy, (2019) demonstrated a significant, long-running relationship between stock prices and domestic interest rates in Turkey's financial markets for the period of 2001 M1-2017M4. Cointegration analysis is investigated using the autoregressive cointegration distributed lag bounds (ARDL Bounds) test and vector autoregressive cointegration. Additionally, cointegration equations such as the Fully Modified Ordinary Least Square (FMOLS), Dynamic Ordinary Least Squares (DOLS), and Canonical Cointegration Regression (CCR) are applied to check the long-run elasticities in the concerned relationship.

Moawad, (2019) examined the relationship between the development of the financial sector and economic growth in France and Malaysia to verify the relations' existence and to determine its direction using the ARDL. The main finding of this study was the existence of a long-term relationship between the development of the financial sector and economic growth in the two countries studied.

Based on the above the present study is aimed to investigate the short- and long-term cointegration relationships between the area and production of Food grain crops grown in India during the period 1950-2018 using an ADRL model and bounds cointegration tests. 


\subsection{ARDL model}

The Autoregressive Distributed Lag (ARDL) models are standard least squares regressions that include lags of both the dependent variable and explanatory variables as regressors (Greene, 2008). Although ARDL models have been used in econometrics for decades, they have gained popularity in recent years as a method of examining cointegrating relationships between variables through the work of Pesaran and Shin (1998) and Pesaran et al. (2001).

In particular, if $y_{t}$ is the dependent variable and are $\mathrm{k} \mathrm{e} x_{1}, x_{2}, \ldots, x_{k}$ xplanatory variables, a general $\operatorname{ARDL}\left(p, q_{1}, q_{2}, \ldots, q_{k}\right)$ model is given by

$$
y_{t}=\alpha_{0}+\alpha_{1} t+\sum_{i=1}^{p} w_{i} y_{t-1}+\sum_{j=1}^{k} \beta_{j, l_{j}} x_{j, t-l_{j}}+\varepsilon_{t}
$$

where $\varepsilon_{t}$ are the usual innovations, $\alpha_{0}$ is the regression constant, and $\alpha_{1}, w_{i}$ and $\beta_{j, l_{j}}$ are the coefficients associated with a linear trend, with lags of $y_{t}$, and with lags of the $\mathrm{k}$ regressors $x_{j, t}$ for $\mathrm{j}=1,2,3, \ldots, \mathrm{k}$, respectively. An $\operatorname{ARDL}(p, q)$ model has $\mathrm{p}$ lags of the dependent variable and $\mathrm{q}$ lags of the independent variable:

$$
y_{t}=\beta_{0}+\beta_{1} y_{t-1}+\ldots+\beta_{p} y_{t-p}+\alpha_{0} x_{t}+\alpha_{1} x_{t-1}+\alpha_{2} x_{t-2}+\ldots+\alpha_{q} x_{t-q}+\mu_{t}
$$

where $\mu_{t}$ is a random "disturbance" term.

The model is "autoregressive" in the sense that $y_{t}$ is "explained" (in part) by lagged values of itself. It also has a "distributed lag" component in the form of successive lags of the " $x$ " explanatory variable. Sometimes, the current value of itself is excluded from the distributed lag part of the model's structure (Soharwardi et.al.,2018).

\subsection{Materials}

\section{MATERIALS AND METHODS}

The present study is to investigate the short- and long-term cointegration relationships between the area and productionof Food grain crops grown in India during the period 19502018 based on the ADRL model. The relevant time series data of Food grain production and the area under the crop have been collected from the Agricultural at Glance - 2019 magazine published by the Ministry of Agriculture, Government of India. Here $\mathrm{x}_{\mathrm{t}}$, is the independent variable, area under the Food grain crops which is denoted by the variable AREAt and $y_{t}$, is the dependent variable, production of Food grain crops which is denoted by the variable 


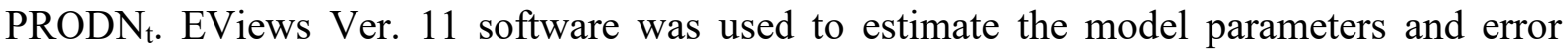
diagnostics and to study the stability of the estimated model. The units of the study variables are Area in Million Hectares and Production in Million Tonnes

\subsection{Methods}

To apply the ARDL model, the study variables should fulfil certain stationarity conditions. That is, the variables should be purely $\mathrm{I}(0)$, purely $\mathrm{I}(1)$ or $\mathrm{I}(0) / \mathrm{I}(1)$ (Alimi, 2014). To test this, three different tests, viz., the Dickey and Fuller (1979), Phillips and Perron (1988) and Kwiatkowski et al. (1992) tests, were used. The Akaike information criterion (AIC) was used to select the optimal lag. To test the normality of the residual, the Jarque-Bera test (Jarque and Bera, 1980) is used. For testing for autocorrelation and serial correlation, the Ljung-Box test (Ljung and Box, 1979) and the Breusch-Godfrey test (Breusch 1978; Godfrey 1978), respectively, were used. To test for heteroscedasticity, the Breusch-Pagan-Godfrey heteroscedasticity test (Godfrey 1978; Breusch and Pagan 1979) was used. Model stability was studied based on the CUSUM and CUSUMSQ tests (Brown et al., 1975). Finally, to test the cointegration (long-run relationship), the bounds test (Pesaran et al., 2001) was employed. The long-run elasticities among predetermined variables are analyzed with the Fully Modified Ordinary Least Square (FMOLS) as proposed by Philips and Hansen (Philips and Hansen,1990), and Dynamic Ordinary Least Squares (DOLS) technique as suggested by Stock and Watson (Stock and Watson, 1993), and Canonical Cointegration Regression (CCR) are applied to check the long-run elasticities in the concerned relationship. Details of these methods have been omitted in this paper and are available extensively in the literature.

\section{RESULTS AND DISCUSSION}

In this section, we provide the empirical findings and their interpretations in sequence.

\subsection{Unit root test}

The results of the ADP, PP and KPSS Unit root tests in Table 1 reveal that both the variables of the study are stationary at level and both the variables are $\mathrm{I}(0)$.

Table 1: Results of the unit root tests (ADF \& PP tests) ( $H_{0}$ : has a unit root)

\begin{tabular}{|c|c|c|c|}
\hline \multirow[t]{2}{*}{ Variables } & $\begin{array}{l}\text { Augmented Dickey- } \\
\text { Fuller test }\end{array}$ & Phillips-Perron test & $\begin{array}{l}\text { Kwiatkowski-Phillips- } \\
\text { Schmidt-Shin (KPSS) test }\end{array}$ \\
\hline & \multicolumn{3}{|c|}{ Intercept \& trend } \\
\hline Area & $3.62417(0.0351)$ & $-3,624107(0.0451)$ & $(0.242241)$ \\
\hline Production & $-4.913315(0.0008)$ & $-4.923325(0.0008)$ & $(0.216021)$ \\
\hline
\end{tabular}


As the KPSS statistics are nonsignificant, the study variables area and prodn are stationary without differencing.

\subsection{Summary statistics}

The summary statistics presented in Table 2 revealthat the area as well as production show a positive trend in the mean values of 121.0129 and 151.4887 , respectively. The production (285.01) has the highest standard deviation.The study variable area is not Normally distributed because the Jarque-Bera test statistic is significant whereas in case of Production data the Jarque-Bera test is non-significant indicating that the second variable production is normally distributed.Both area as well as production are positively leptokurtic according to the kurtosis values 5.506644 and 1.909159 , respectively. The trends of the study variables are depicted in Fig.1. and Fig.2.

Table 2 : Descriptive Statistics

\begin{tabular}{|l|c|c|}
\hline \multicolumn{1}{|c|}{ Statistics } & Area & Production \\
\hline Mean & 121.0129 & 151.4887 \\
\hline Median & 123.1000 & 143.4200 \\
\hline Maximum & 131.1600 & 285.0100 \\
\hline Minimum & 96.96000 & 50.82000 \\
\hline Std. Dev. & 7.068635 & 67.18510 \\
\hline Skewness & -1.541332 & 0.301316 \\
\hline Kurtosis & 5.506644 & 1.909159 \\
\hline Jarque-Bera & 45.38500 & 4.465164 \\
\hline Probability & 0.000000 & 0.107251 \\
\hline Sum & 8349.890 & 10452.72 \\
\hline Sum Sq. Dev. & 3397.661 & 10452.72 \\
\hline Observations & 69 & 69 \\
\hline
\end{tabular}

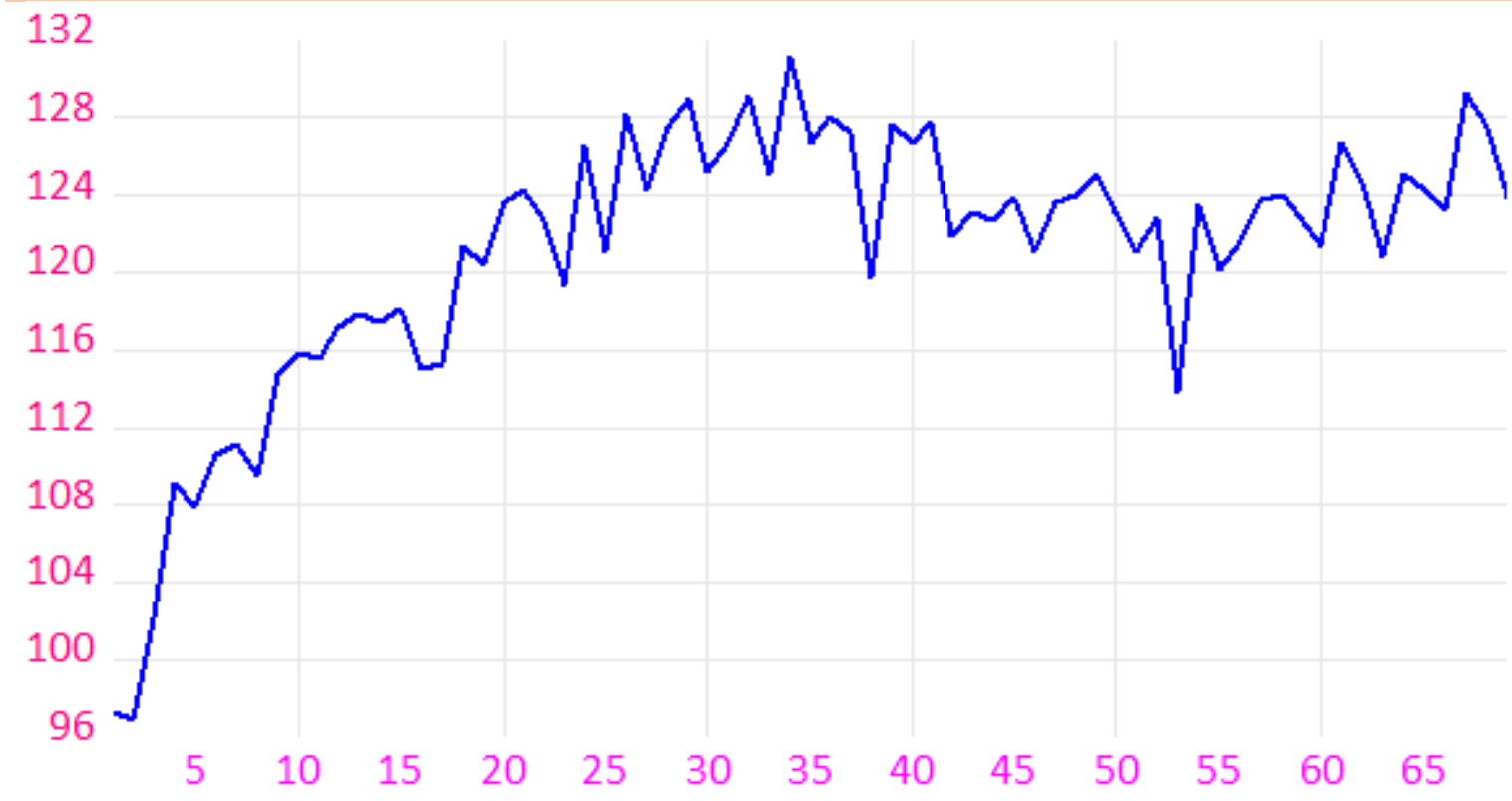

Fig.1. Trends in Area under the Food grain crops in India 


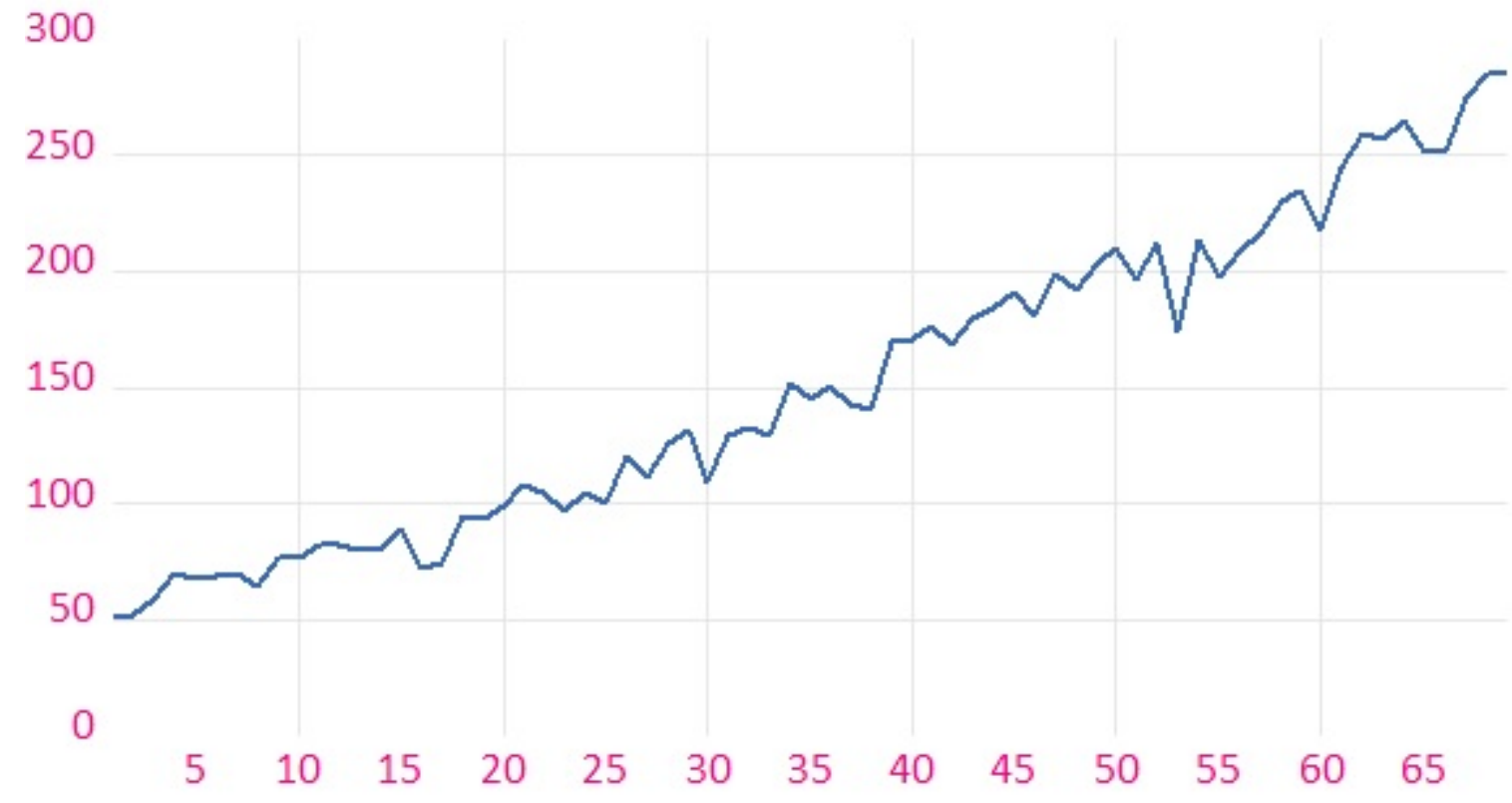

Fig.2. Trends in Food grain production in India

\subsection{Model selection}

To choose the optimal lag values, $p$ and $q$, AIC was calculated for the different values of $p$ and q. The lower the AIC values, the better the lag values for $\mathrm{p}$ and q. Fig.3 illustrates that the AIC value is extremely low for lags $p=4$ and $q=4$. Accordingly, the ARDL $(4,4)$ model is found to be the best among the 20 models investigated with different lag values.

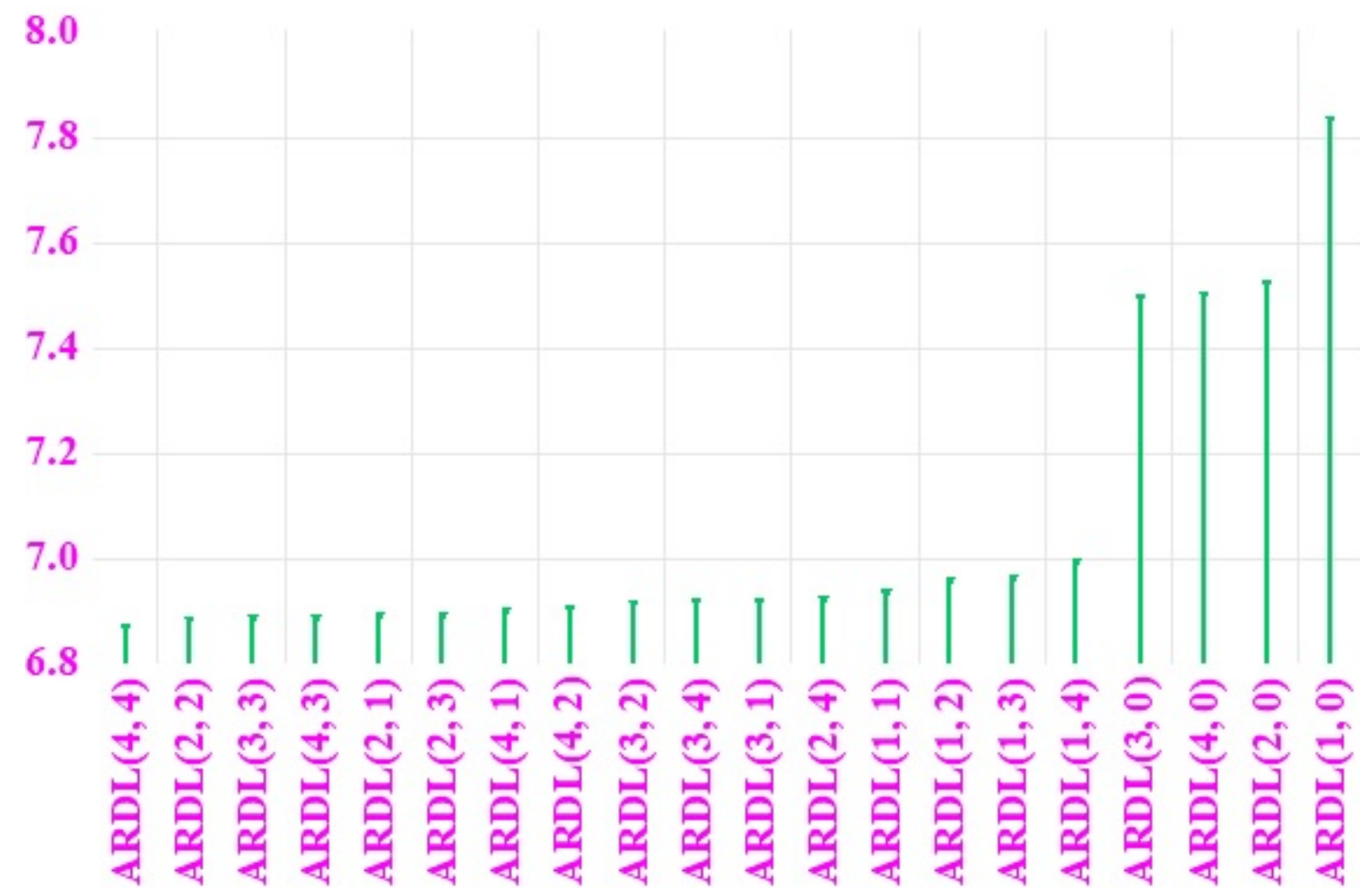

Fig.3. Selection of the appropriate model based on the AIC. 


\subsection{ARDL $(4,4)$ model}

The ARDL $(p=4, q=4)$ model was employed to study the short-run relationship between the area under the Food grain crops and its production. The fitted model is highly significant and the co-efficient of determination is $99 \%$ which is remarkably high. Hera area and production at lag one are highly significant. Additionally, production at lag 4 and area at lag 1 are significant at 5\% level. All the model parameters are significant except the second lag variables of AREA as well as PROD. The value of the D-W statistic is equal to two, which confirms that there are no spurious results.

The estimated model $\operatorname{ADRL}(4,4)$ is

PRODN $=0.5886 *$ PRODN(-1)+0.1303*PRODN(-2)+0.0306*PRODN(-3)+ 0.2837*PRODN($4)+2.9959 *$ AREA - $1.4245 * \operatorname{AREA}(-1)+0.1157 * \mathrm{AREA}(-2)-0.2578 * \mathrm{AREA}(-3)-$ $0.7721 *$ AREA(-4) - 80.3436

Table 3: Results of the estimated ARDL(3,2) model

\begin{tabular}{|c|c|c|c|c|}
\hline Variable & Coefficient & Std. Error & t-Statistic & Prob.* \\
\hline PRODN(-1) & 0.588598 & 0.130631 & 4.505794 & 0.0000 \\
\hline PRODN(-2) & 0.130321 & 0.152819 & 0.852782 & 0.3975 \\
\hline PRODN(-3) & 0.030608 & 0.151255 & 0.202361 & 0.8404 \\
\hline PRODN(-4) & 0.283714 & 0.131608 & 2.155753 & 0.0355 \\
\hline AREA & 2.995887 & 0.324010 & 9.246274 & 0.0000 \\
\hline $\operatorname{AREA}(-1)$ & -1.424465 & 0.510499 & -2.790338 & 0.0072 \\
\hline $\operatorname{AREA}(-2)$ & 0.115728 & 0.548939 & 0.210822 & 0.8338 \\
\hline $\operatorname{AREA}(-3)$ & -0.257828 & 0.529427 & -0.486993 & 0.6282 \\
\hline $\operatorname{AREA}(-4)$ & -0.772123 & 0.452716 & -1.705537 & 0.0937 \\
\hline $\mathrm{C}$ & -80.34362 & 26.83763 & -2.993693 & 0.0041 \\
\hline R-squared & 0.990034 & \multicolumn{2}{|c|}{ Mean dependent var } & 157.2445 \\
\hline Adjusted R-squared & 0.988403 & \multicolumn{2}{|c|}{ S.D. dependent var } & 64.89974 \\
\hline S.E. of regression & 6.988877 & \multicolumn{2}{|c|}{ Akaike info criterion } & 6.867155 \\
\hline Sum squared resid & 2686.442 & \multicolumn{2}{|c|}{ Schwarz criterion } & 7.201676 \\
\hline Log likelihood & -213.1825 & \multicolumn{2}{|c|}{ Hannan-Quinn criter. } & 6.999145 \\
\hline F-statistic & 607.0979 & \multicolumn{2}{|c|}{ Durbin-Watson stat } & 2.073624 \\
\hline Prob(F-statistic) & 0.000000 & & & \\
\hline
\end{tabular}

\subsection{Test for normality of the residuals}

Fig.4. illustrates that the errors are normally distributed, as the Jarque-Bera test statistic's value is 2.935828 with the $p=0.230406$ which is non-significant, and the value of kurtosis is equal to 2.8856 . 


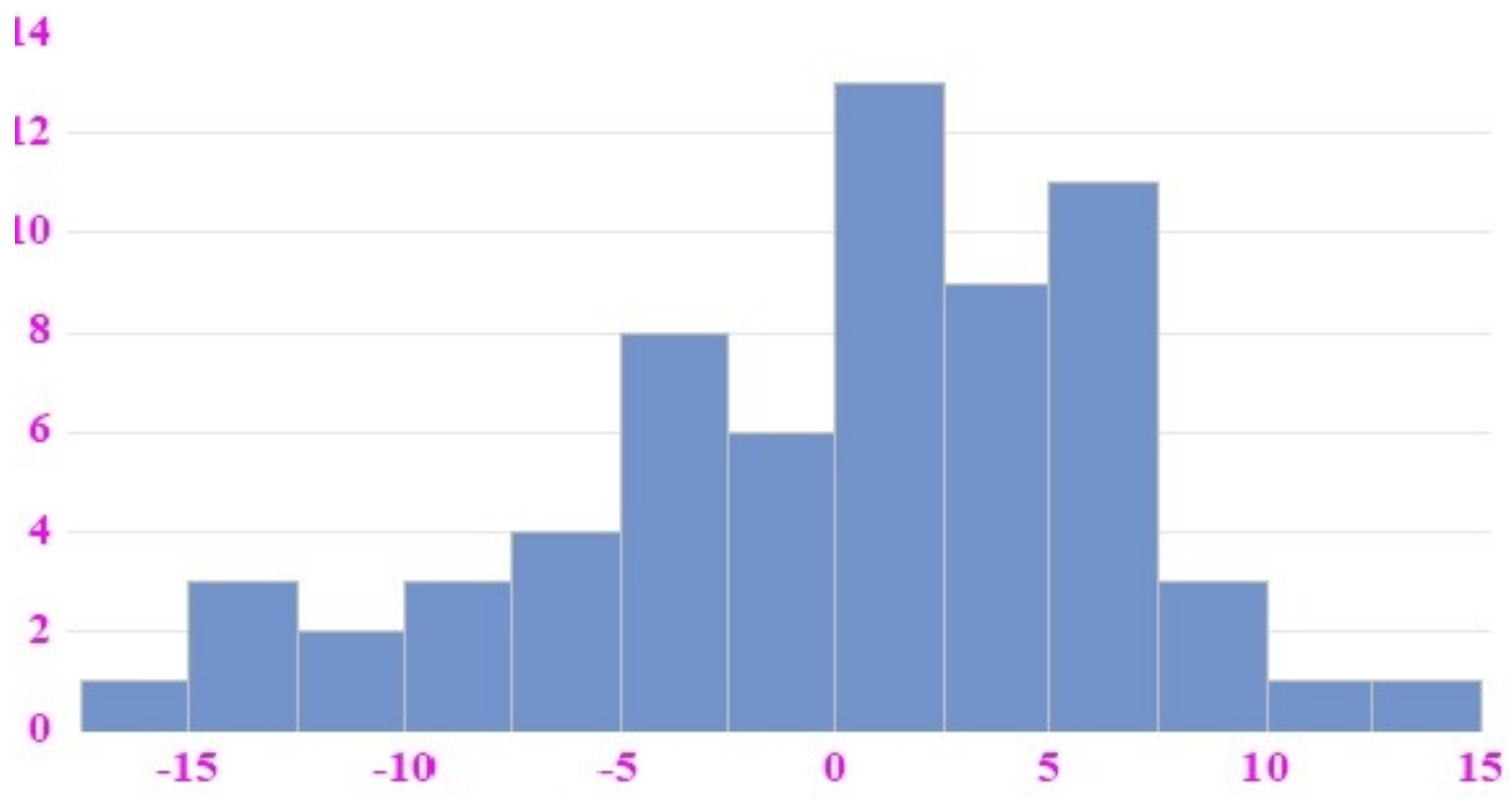

Fig.4. Test for normality of residuals.

To ensure the consistency of the ARDL $(4,4)$ model, the following residual diagnostic tests are carried out.

\subsection{Ljung-Box test for autocorrelation}

The results of the Ljung-Box autocorrelation test (Ljung and Box 1979) presented in Table 4 indicate that the $\mathrm{p}$-values of the $\mathrm{Q}$ statistics are clearly greater than 0.05 and strongly suggest the absence of autocorrelation in the model error.

Table 4: Results of the autocorrelation test

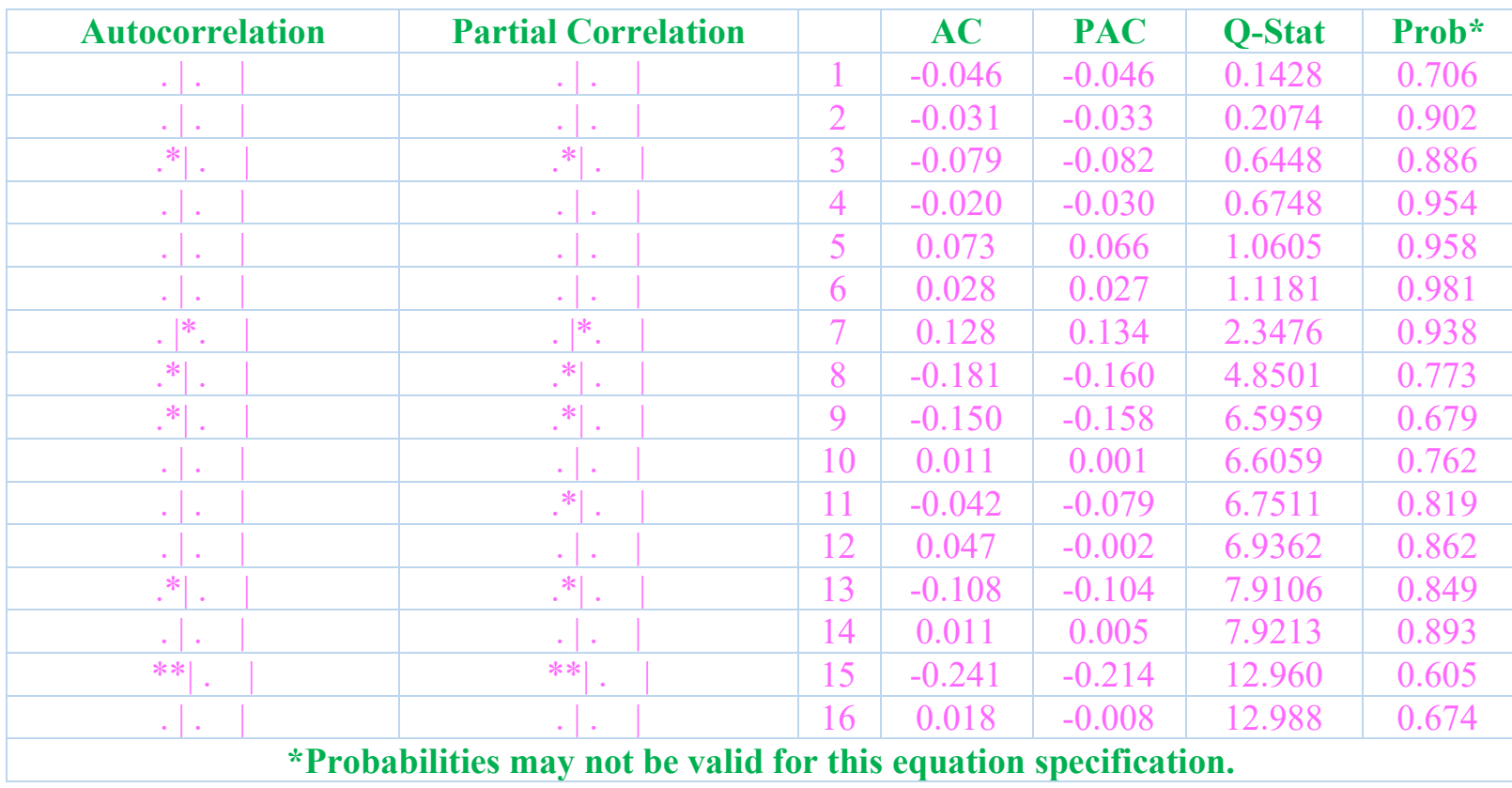




\subsection{Breusch-Godfrey serial correlation LM test (Breusch, 1978; Godfrey, 1978)}

Usually, when an analysis involves time-series data, the possibility of serial correlation is high. Therefore, it is necessary to test the residuals for serial correlation using the BreuschGodfrey LM test. The results presented in Table 5 reveal that the null hypothesis of no serial correlation can be accepted since the p-value for the test is greater than 0.05 , and hence, there is no serial correlation.

Table 5: Results of the Breusch-Godfrey Serial-Correlation LM test of the residuals

\begin{tabular}{|l|c|l|l|}
\hline F-statistic & 0.757615 & Prob. F(2,53) & 0.4738 \\
\hline Obs*R-squared & 1.806650 & Prob. Chi-Square(2) & 0.4052 \\
\hline
\end{tabular}

\subsection{Breusch-Pagan-Godfrey heteroscedasticity test}

To ensure consistency, the study further employed the Breusch-Pagan-Godfrey heteroscedasticity test, and the results are presented in Table 6 . The results reveal that the null hypothesis of no heteroscedasticity is accepted, as the test is non-significant (the p-value is greater than 5\%). Hence the mean and variance are remains same throughout the study period.

Table 6: Characteristics of the Breusch-Pagan-Godfrey heteroscedasticity test.

\begin{tabular}{|l|l|l|l|}
\hline F-statistic & 1.915272 & Prob. F(9,55) & 0.0687 \\
\hline Obs*R-squared & 15.51043 & Prob. Chi-Square(9) & 0.0778 \\
\hline Scaled explained SS & 10.46999 & Prob. Chi-Square(9) & 0.3138 \\
\hline
\end{tabular}

The significance in the outcome of serial correlation, heteroscedasticity and test for normality indicate that the fitted model $\operatorname{ADRL}(4,4)$ is the well fitted model.

\subsection{Fit of the model}

The actual and fitted plot of the ARDL $(4,4)$ model shows that the fit enough in terms of explaining the production of the Food grain crops and future forecasts (Fig.5.). 


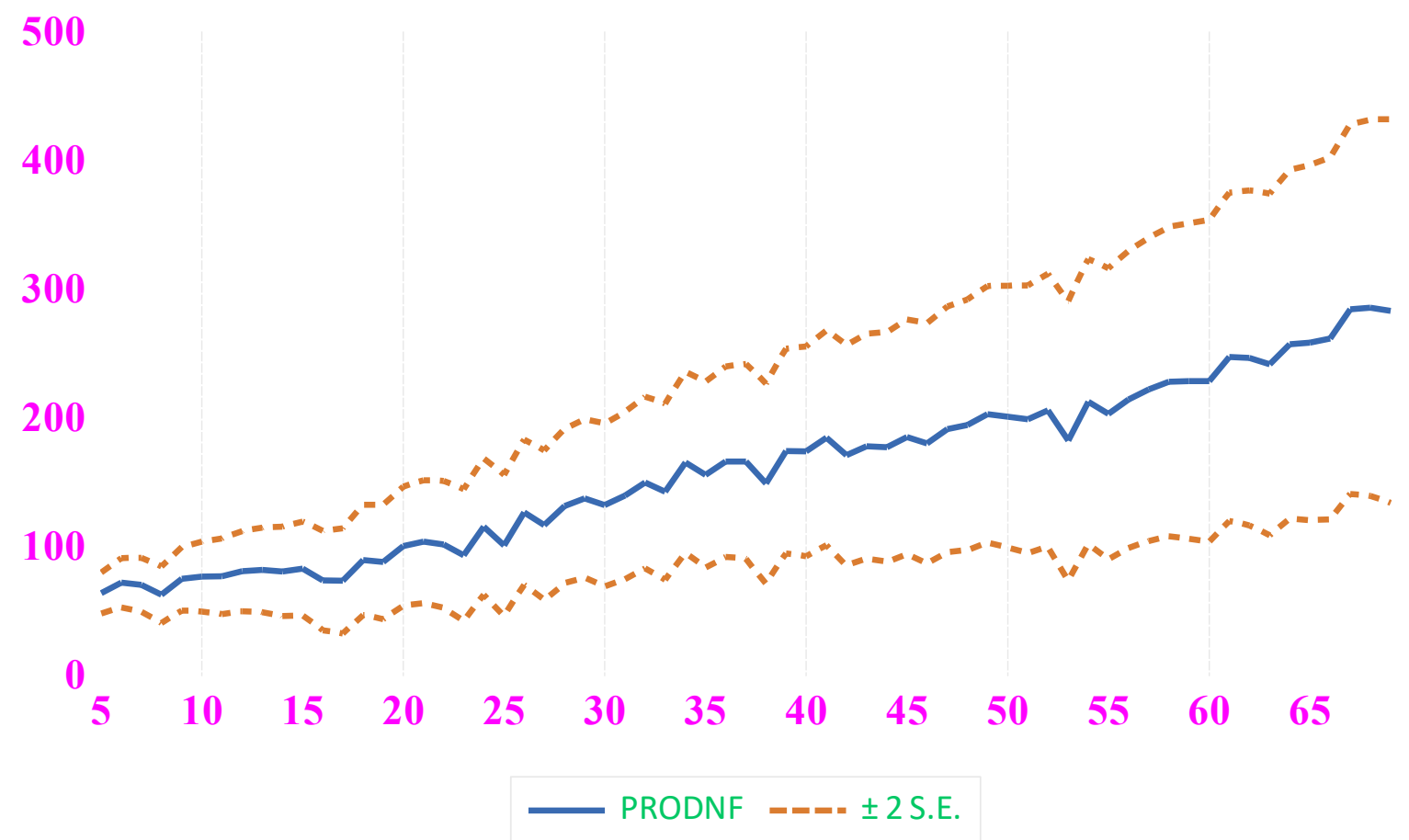

Fig.5:Fit of the estimated model ADRL $(4,4)$ for production

\subsection{Model stability}

To check the robustness of our results, structural stability tests of the parameters of the longrun results are performed by the CUSUM and CUSUMSQ tests (Brown et al. 1975). This same procedure has been utilised by Pesaran and Pesaran (1997) and Mohsen et al. (2002) to test the stability of long-run coefficients. A graphical representation of the CUSUM and CUSUMSQ statistics is shown in Figs.6 and 7, respectively. The plots of both the CUSUM and CUSUMSQ are within the boundaries of the 5\% significance level, and these statistics confirm the model's stability. 


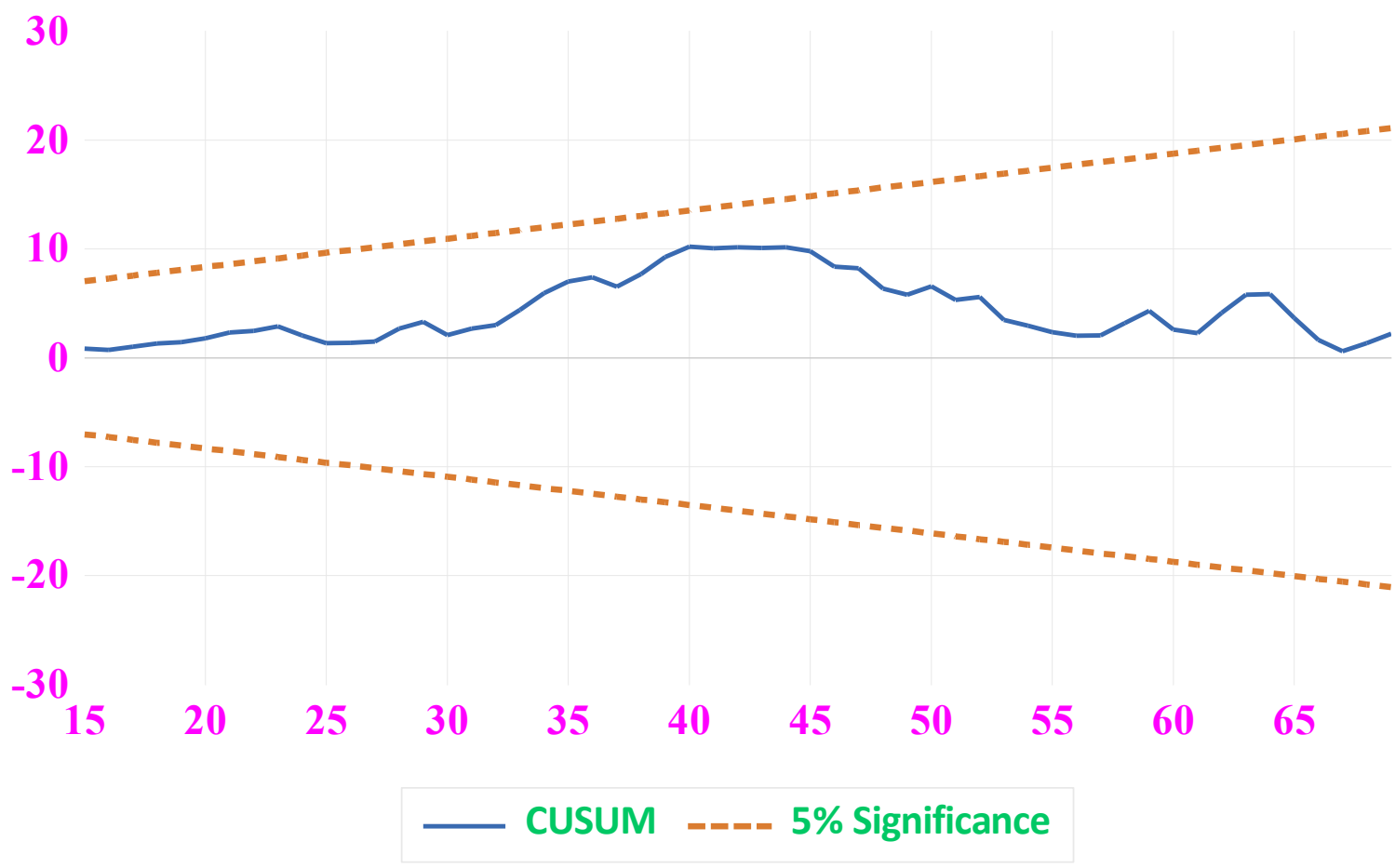

Fig.6.: CUSUM stability test.

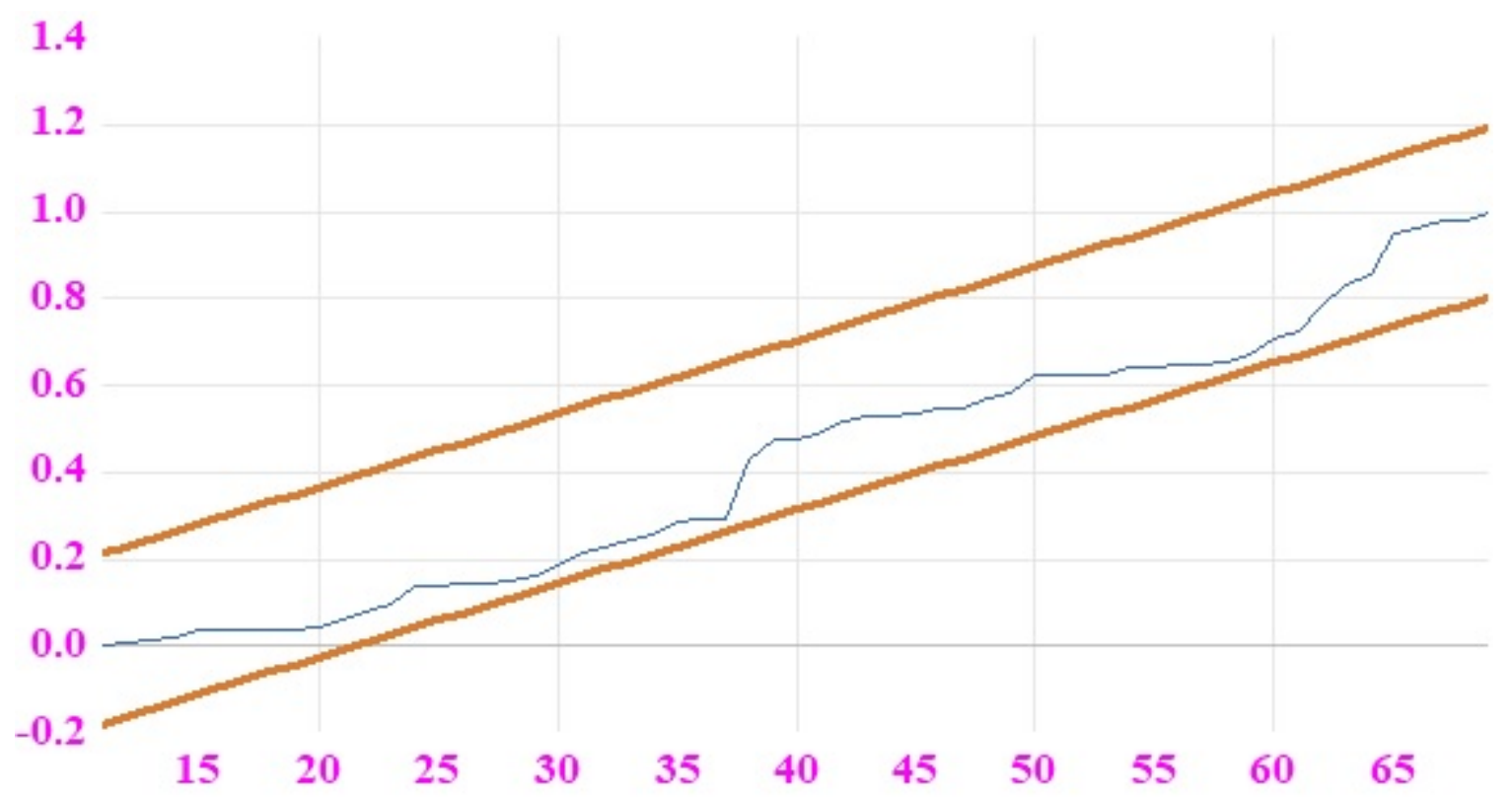

Fig.7.: CUSUMSQ stability test

\subsection{Bounds test for cointegration}

The bounds test developed by Pesaran et al. (2001) is employed to test the cointegration (long-run relationship) between the study variables area and production and is presented in Table 7. The test results reveal that there exists a cointegration relationship between area and production, as the bounds test statistic is greater than the upper bound from I(1) (F-statistics 
$=9.098144>5.58)$, and hence the null hypothesis of "No levels Relationships" is rejected, which impliesthe possibility of a log-run relationship between the study variables,area under the Food Grain crops (AREA)and production (PRODN).

Table 7: Bound Test Results

\begin{tabular}{|c|c|c|c|c|}
\hline Test Statistic & Value & Signif. & I(0) & I(1) \\
\hline F-statistic & 9.098144 & $10 \%$ & 3.02 & 3.51 \\
\hline $\mathrm{k}$ & 1 & $5 \%$ & 3.62 & 4.16 \\
\hline & & $2.5 \%$ & 4.18 & 4.79 \\
\hline
\end{tabular}

The conditional error correction regression model is presented in Table 8. All the estimated parameter values are significant except production at lag 1 and first difference in production at lag one and three.

Table - 8 : Conditional Error CorrectionRegression Results

\begin{tabular}{|c|c|c|c|c|}
\hline Variable & Coefficient & Std. Error & t-Statistic & Prob. \\
\hline C & -80.34362 & 26.83763 & -2.993693 & 0.0041 \\
\hline PRODN(-1)* & 0.033242 & 0.017552 & 1.893843 & 0.0635 \\
\hline AREA(-1) & 0.657199 & 0.226983 & 2.895371 & 0.0054 \\
\hline D(PRODN(-1)) & -0.444643 & 0.134567 & -3.304245 & 0.0017 \\
\hline D(PRODN(-2)) & -0.314322 & 0.142743 & -2.202009 & 0.0319 \\
\hline D(PRODN(-3)) & -0.283714 & 0.131608 & -2.155753 & 0.0355 \\
\hline D(AREA) & 2.995887 & 0.324010 & 9.246274 & 0.0000 \\
\hline D(AREA(-1)) & 0.914222 & 0.473570 & 1.930490 & 0.0587 \\
\hline D(AREA(-2)) & 1.029951 & 0.475382 & 2.166574 & 0.0346 \\
\hline D(AREA(-3)) & 0.772123 & 0.452716 & 1.705537 & 0.0937 \\
\hline
\end{tabular}

The results presented in Table 9 the estimates of the long run variables. The error correction equation is $\mathbf{E C}=\mathbf{P R O D N}-\mathbf{( - 1 9 . 7 7 0 4 * A R E A}+\mathbf{2 4 1 6 . 9 6 6 3 )}$

Table 9 : Levels Equation Results

\begin{tabular}{|c|c|c|c|c|}
\hline Variable & Coefficient & Std. Error & t-Statistic & Prob. \\
\hline AREA & -19.77042 & 14.10325 & -1.401835 & 0.1666 \\
\hline C & 2416.966 & 1653.236 & 1.461961 & 0.1494 \\
\hline
\end{tabular}

The results present in the Table 10 is the errors correction model estimates the speed of adjustment to equilibrium in a cointegration relationship. Here, the error correction term derived as the Levels Equation earlier, is included among the regressors and is denoted as CointEq. The coefficient associated with this regressor is typically the speed of adjustment to 
equilibrium in every period. Here the Coefficient of CointEq is positive and highly significant.Thus, both the variables under study are moving together in positive direction.

Table 10 : ARDL ECM Regression Results

\begin{tabular}{|c|c|c|c|c|}
\hline Variable & Coefficient & Std. Error & t-Statistic & Prob. \\
\hline D(PRODN(-1)) & -0.444643 & 0.131684 & -3.376581 & 0.0014 \\
\hline D(PRODN(-2)) & -0.314322 & 0.139546 & -2.252467 & 0.0283 \\
\hline D(PRODN(-3)) & -0.283714 & 0.128760 & -2.203437 & 0.0318 \\
\hline D(AREA) & 2.995887 & 0.290811 & 10.30182 & 0.0000 \\
\hline D(AREA(-1)) & 0.914222 & 0.443186 & 2.062841 & 0.0439 \\
\hline D(AREA(-2)) & 1.029951 & 0.449602 & 2.290806 & 0.0258 \\
\hline D(AREA(-3)) & 0.772123 & 0.437695 & 1.764068 & 0.0833 \\
\hline CointEq(-1)* & 0.033242 & 0.006250 & 5.318548 & 0.0000 \\
\hline R-squared & 0.752570 & Mean dependent var & 3.309692 \\
\hline Adjusted R-squared & 0.722184 & S.D. dependent var & 13.02485 \\
\hline S.E. of regression & 6.865170 & Akaike info criterion & 6.805617 \\
\hline Sum squared resid & 2686.442 & Schwarz criterion & 7.073234 \\
\hline Log likelihood & -213.1825 & Hannan-Quinn criter. & 6.911209 \\
\hline Durbin-Watson stat & 2.073624 & \multicolumn{3}{l|}{} \\
\hline
\end{tabular}

\subsection{Johnson Cointegration test}

Like the ARDL and cointegration equation, the Johnsen cointegration results produce the same evidence for one cointegrating vector. Table 11 represents the Trace and Max-Eigen statistics. Both the statics values are significant indicating the existence of one cointegration relationships between the study variables, which confirms the results of the ARDL Bounds Tests.

Table 11. Johansen Cointegration Test Results

\begin{tabular}{|c|c|c|c|c|}
\hline No. of $\mathrm{CE}(\mathrm{s})$ & Eigenvalue & Trace Statistic & $0.05 \%$ Critical Value & Prob.** \\
\hline None $*$ & 0.258187 & 20.02937 & 15.49471 & 0.0097 \\
\hline At most 1 & 0.014199 & 0.915227 & 3.841465 & 0.3387 \\
\hline & $\begin{array}{l}\text { test indicat } \\
\text { enotes rejed } \\
* * \text { MacKin }\end{array}$ & $\begin{array}{l}\text { ointegrating e } \\
\text { of the hypothe } \\
\text { Iaug-Michelis }\end{array}$ & $\begin{array}{l}\text { (s) at the } 0.05 \text { level ; } \\
\text { at the } 0.05 \text { level; } \\
\text { 999) p-values }\end{array}$ & \\
\hline
\end{tabular}

\subsection{Long-Run Elasticities}

As there exists cointegration among the study variables, long-run elasticities are estimated with the FMOLS, DOLS and CCR equations by considering production as the regress and area as the regressor. The results are reported in Table 12.The finding shows that as the $1 \%$ increase in area under the crop cases nearly $6 \%$ increases in production. 
Table 12.Long-run elasticities for the dependent variable PRODUCTION (PRODN)

\begin{tabular}{|c|c|c|c|}
\hline Variables & FMOLS & DOLS & CCE \\
\hline Area & $\begin{array}{l}5.5395^{*} \\
(1.9897) \\
{[2.7840]}\end{array}$ & $\begin{array}{l}5.9675^{*} \\
(2,6567) \\
{[2.2463]}\end{array}$ & $\begin{array}{l}5.5504 \\
(1.9076) \\
{[2.9097]}\end{array}$ \\
\hline Constant & $\begin{array}{l}-526.4692^{*} \\
(1.9897) \\
{[2.7840]}\end{array}$ & $\begin{array}{l}-571.4930 \\
(325.4917) \\
{[-1,7558]}\end{array}$ & $\begin{array}{l}-517.7741^{*} \\
(231.3262) \\
{[-2.2383]}\end{array}$ \\
\hline $\mathbf{R}^{2}$ & $31 \%$ & $32 \%$ & $31 \%$ \\
\hline $\operatorname{Adj} \cdot R^{2}$ & $30 \%$ & $27 \%$ & $30 \%$ \\
\hline S.E. of Regression & 55.6190 & 54.7909 & 55.6183 \\
\hline
\end{tabular}

The cointegration results from the ARDL bounds Test and the long-run elasticities are corroborated with the Johansen cointegration method.

\section{CONCLUSION}

The estimated ARDL ( $p=4, q=4)$ model is highly significant, and the value of the coefficient of determination, $\mathrm{R}^{2}=99 \%$, implies that almost $99 \%$ of the variation in the dependent variable is explained by the model and that the rest is explained by the error term. The estimated model is found to be, no serial correlations, presences of homoskedastic and the errors are normally distributed. The value of the D-W statistic is nearly equal to two, which confirms that there are no spurious results. The bounds test results reveal that a log-run relationship between the area under the food grain crops and its production. The error correction term is positive and highly significant, which is the one of the desirable qualities of the model which reflects the variables under study are moving together in positive direction. The finding shows that as the $1 \%$ increase in area under the crop cases nearly $6 \%$ increases in production.

\section{ACKNOWLEDGEMENTS}

Authors are highly thankful to Dr.K. Senthamari Kannan, Senior Professor and Head, Department of Statistics, Manonmaniam Sundaranar University, Tirunelveli-621 012, Tamil Nadu State, India, for helpful discussion and encouragement while preparing this paper. 


\section{REFERENCES}

[1] Alimi, R.S., ARDL Bounds Testing Approach to Cointegration: A Re-Examination of Augmented Fisher Hypothesis in an Open Economy, Asian Journal of Economic Modelling, 2014,2, 103-114.

[2] Breusch, T.S., Testing for Autocorrelation in Dynamic Linear Models, Australian Economic Papers, 1978,17, 334-355.

[3] Breusch, T.S., and Pagan, A.R., A Simple Test for Heteroscedasticity and Random Coefficient Variation, Econometrica,1979,47, 1287-1294.

[4] Brown, R.L., Durbin, J., and Evans, J.M., 1975, Techniques for Testing the Constancy of Regression Relationships over Time, Journal of the Royal Statistical Society. Series B (Methodological), 1975, 37, 149-192.

[5] Chandio,A.A., Jiang, Y., and Rehman, A., Using the ARDL-ECM approach to investigate the nexus between support price and wheat production, Journal of Asian Business and Economic Studies, 2019, 26(1), 139-152.

[6] Dickey, D.A., and Fuller, W.A., 1979, Distribution of the Estimators for Autoregressive Time Series with a Unit Root, Journal of the American Statistical Association, 1979,74, 427-431.

[7] Godfrey, L.G., Testing Against General Autoregressive and Moving Average Error Models when the Regressors Include Lagged Dependent Variables, Econometrica, 1978,46, 1293-1301.

[8] Granger, C.W.J., Some Recent Development in A Concept of Causality, Journal of Econometrics, 1988, 39, 7-21.

[9] Greene, W.H., Econometric Analysis, 2008, Pearson Prentice Hall, Upper Saddle River, NJ.

[10] Jarque, C.M., and Bera, A.K., Efficient Tests for Normality, Homoscedasticity and Serial Independence of Regression Residuals, Economics Letters, 1980, 6, 255-259.

[11] Kwiatkowski, D., Phillips, P.C.B., Schmidt, P., and Shin, Y., Testing the Null Hypothesis of Stationarity Against the Alternative of a Unit Root, Journal of Econometrics, 1992,54, 159-178.

[12] Ljung, G.M., and Box, G.E.P., The Likelihood Function of Stationary AutoregressiveMoving Average Models, Biometrika,1979, 66, 265-270.

[13] Moawad, R.R., Financial Development and Economic Growth: ARDL Model, International Multilingual Journal of Science and Technology, 2019,4, 625-632.

[14] Mohsen, Bahmani-Oskooee and Ng, R.W., Long run demand for money in Hong Kong: An application of the ARDL model, International Journal of Business and Economics, 2002, 1(2), 147-155. 
[15] Nkoro,E., and Uko,A.K., 2016, Autoregressive Distributed Lag (ARDL) cointegration technique: application and interpretation, Journal of Statistical and Econometric Methods, SCIENPRESS Ltd, 5(4),1-3.

[16] Pesaran, M.H., and Pesaran, B., Working with Microfit 4.0: Interactive Econometric Analysis, 1997, Oxford University Press, Oxford, UK.

[17] Pesaran, M.H. and Shin, Y., An Autoregressive Distributed-Lag Modelling Approach to Cointegration Analysis, Econometrics and Economic Theory in the 20th Century: The Ragnar Frisch Centennial Symposium, 1998, 31, 371-413. http://dx.doi.org/10.1017/CCOL0521633230.011

[18] Pesaran, M.H., Shin, Y., and Smith, R.J., Bounds Testing Approaches to the Analysis of Level Relationships, Journal of Applied Economics, 2001,16, 289-326.

[19] Phillips, P.C., and Hansen, B.E., Statistical inference in instrumental variables regression with I(1) processes, Rev.Econ.Stud, 1990,57(1), 99-125.

[20] Phillips, P.C.B., and Perron, P., Testing for a Unit Root in Time Series Regression, Biometrika, 1988,75, 335-346.

[21] Soharwardi,M.A.,Khan, R.E.A., Mushtaq, S., Long-run and short-run relationship between financial development and income inequality in Pakistan. Journal of ISOSS, 2018, 4(2),105-112.

[22] Stock, J.H., and Watson,M.W., A simple estimator of cointegrating vectors in higher order integrated systems, Econometrica: Journal of the Econometric Society, 1993, $783-820$

[23] Zaefizadah M., Khayatnezhad M., and Ghlaomin M., Comparison of Multiple Linear Regression (MLR) and Artificial Neural Network (ANN) in Predicting the Yield Using its Components in the Hulless Barley, J. Agriculture and Environmental Sciences., 2011,10(1), 60-64. 